\title{
Pengembangan LKPD mobile learning guided discovery untuk meningkatkan penguasaan kompetensi dasar ekosistem Kurikulum 2013
}

\author{
Asri Puspitasari ${ }^{1}{ }^{*}$, Rio Christy Handziko ${ }^{2}$ \\ ${ }^{1}$ Program Studi Pendidikan Biologi, Program Pascasarjana Universitas Negeri Yogyakarta. \\ ${ }^{2}$ Program Studi Pendidikan Biologi, Fakultas Matematika dan Ilmu Pengetahuan Alam, Universitas \\ Negeri Yogyakarta. Jalan Colombo No. 1, Karangmalang, Yogyakarta 55281, Indonesia. \\ * Coressponding Author. E-mail: asri.puspita02@gmail.com \\ Received: 23 November 2017; Revised: 14 September 2018; Accepted: 18 September 2018
}

\begin{abstract}
Abstrak
Penelitian ini bertujuan (1) mengembangkan produk aplikasi LKPD Mobile Learning berbasis Guided Discovery yang layak sebagai bahan ajar dan (2) mengetahui keefektifan penggunaannya terhadap peningkatan penguasaan kompetensi dasar (KD) peserta didik pada pokok bahasan ekosistem dalam kurikulum 2013. Penelitian pengembangan ini merupakan Design and Development Research (D \& D R) menurut Ellis dan Levy. Subjek coba penelitian sebanyak 126 peserta didik kelas X dari SMA N 1 Sentolo dan SMA N 1 Temon Kabupaten Kulon Progo. Data dikumpulkan dengan menggunakan instrumen validasi ahli, instrumen tes pengukuran kompetensi pengetahuan, dan lembar observasi penguasaan kompetensi keterampilan. Hasil penelitian menunjukkan bahwa (1) aplikasi LKPD Mobile Learning berbasis Guided Discovery pada pokok bahasan Ekosistem ditinjau dari penilaian pada aspek kelayakan materi, tampilan, bahasa, dan kehandalan termasuk dalam kategori baik, dan (2) penerapan LKPD Mobile Learning berbasis Guided Discovery pada pokok bahasan Ekosistem dalam proses pembelajaran secara signifikan mampu meningkatkan penguasaan kompetensi dasar peserta didik.
\end{abstract}

Kata Kunci: guided discovery, kompetensi dasar, Kurikulum 2013, LKPD, mobile learning

\section{Developing guided discovery mobile learning worksheet to improve student's mastery of basic competence in Curriculum 2013}

\begin{abstract}
The aims of this research were (1) to produce Guided Discovery mobile learning worksheet on Ecosystem subject matter, (2) to know the effectiveness on student's Mastery of Basic Competence in Curriculum 2013. This research is Design and Development Research (D\&D R) according to Ellis and Levy. Product as the result of this development research was tested to subject of this research, 126 ten grade students of SMA N 1 Sentolo and SMA N 1 Temon, Kulon Progo. Data were collected through validation instrument set, basic competence instrument test, and observation sheet to assest process skill competence. The result of this recearch showed that (1) Guided Discovery mobile learning worksheet on Ecosystem subject matter was appropriate for students based on the contain, interface, language, and reliability and got good catergory rating, and (2) was effective and significant to improve student's mastery of Basic Competence in Curriculum 2013.
\end{abstract}

Keywords: basic competence, Curriculum 2013, guided discovery, mobile learning, worksheet

How to Cite: Puspitasari, A., \& Handziko, R. (2018). Pengembangan LKPD mobile learning guided discovery untuk meningkatkan penguasaan kompetensi dasar ekosistem Kurikulum 2013. Jurnal Inovasi Pendidikan IPA, 4(1), 83-97. doi:http://dx.doi.org/10.21831/jipi.v4i1.17003

http://dx.doi.org/10.21831/jipi.v4i1.17003

\section{PENDAHULUAN}

Pembelajaran sains, sama halnya seperti penemuan sains, harus diajarkan sebagai suatu proses menemukan sesuatu, dengan melibatkan keterampilan dan sikap tertentu (Chiappetta, \& Koballa Jr, 2014, p.89). Pembelajaran sains me- 
libatkan pengembangan pemahaman konseptual, prosedural, dan juga pemahaman terhadap pengetahuan alam (Moeed, 2015, p.1). Dalam sains, terdapat tiga elemen utama, yaitu proses (metode ilmiah), produk, dan sikap manusia (Sund \& Carin, 1989, p.5). Prayitno (2011) menyatakan "pembelajaran Biologi di Indonesia sebagian besar terbatas pada aspek produk. Pembelajaran yang terbatas pada aspek produk menyebabkan pembelajaran berbasis isi. Keberhasilan pembelajaran berbasis isi diukur dari banyaknya konsep yang berhasil dihafalkan oleh peserta didik." Akibat yang dapat ditimbulkan dari pembelajaran berbasis isi adalah tidak tercapainya aspek proses dan sikap yang harus dikembangkan sebagai bagian dari pembelajaran sains.

Tantangan ke depan yang dihadapi oleh sekolah dalam menyelenggarakan pendidikan sains adalah menyediakan pengalaman belajar yang memungkinkan peserta didik untuk menyelidiki, mempelajari ide-ide sains, mempelajari banyak pendekatan yang dapat dilakukan untuk melakukan investigasi sains, dan mengembangkan suatu pemahaman mengenai pengetahuan alam (Moeed, 2015, p.1). Dengan kemajuan teknologi yang sangat pesat di era milenial saat ini, pemanfaatan teknologi aplikatif yang digunakan peserta didik dalam kehidupan sehari-hari sangat diperlukan dalam mendukung proses pembelajaran sains. Interaksi peserta didik dengan perangkat teknologi seperti telepon genggam yang lebih banyak dibanding dengan perangkat lain, merupakan suatu kelebihan yang dimiliki oleh telepon genggam. Sehingga pemanfaatan yang lebih dalam proses pembelajaran perlu dipertimbangkan.

Susilana \& Riyana (2008, p.1) menyatakan "pembelajaran merupakan suatu kegiatan yang melibatkan seseorang dalam upayanya memperoleh pengetahuan, keterampilan, dan nilai-nilai positif dengan memanfaatkan berbagai sumber untuk belajar. Hal terpenting dalam pembelajaran adalah terjadinya proses belajar." Smaldino, Lowther, Russell, \& Mims (2011, p.11) mendefinisikan "belajar adalah perubahan yang terjadi secara terus-menerus dalam hal kemampuan yang berasal dari pengalaman dan interaksi pembelajar dengan dunia. Belajar merupakan pengembangan pengetahuan, keterampilan, dan atau sikap ketika seseorang berinteraksi dengan informasi dan lingkungan. Pada era milenial ini pengalaman belajar dapat berbetuk aktual maupun virtual dan dapat berlangsung dengan atau tanpa bantuan teknologi."
Akses informasi dan perkembangan teknologi di abad-21 memudahkan siapa saja dapat mengakses berbagai macam hal dengan cepat. Berbagai informasi dapat diakses siapa saja, kapan saja, dimana saja dengan menggunakan berbagai perangkat yang tersambung dengan jaringan internet. Pemanfaatan teknologi dan internet dapat dimanfaatkan untuk mendukung proses belajar peserta didik. Kemudahan akses terhadap teknologi dan informasi menyebabkan setiap orang dengan mudahnya mengunggah dan mengedit segala macam bentuk informasi. Informasi yang sedianya valid dan dapat dipertanggung jawabkan kebenarannya menjadi hal yang tidak mudah untuk diperoleh, terlebih informasi yang diperoleh akan digunakan peserta didik dalam proses pembelajaran.

Mobile learning sering disebut sebagai $m$ Learning adalah pembelajaran yang dilaksanakan dengan penggunaan perangkat komputasi portabel yang berukuran kecil. Perangkat komputasi ini meliputi: smartphone, personal digital assistant (PDA) dan perangkat genggam lain yang serupa (Behera, 2015, p.35). m-Learning bukan hanya menyajikan konten pembelajaran ke dalam perangkat telepon genggam, melainkan mengenai proses untuk memperoleh pengetahuan dan mampu menjalankannya dengan baik melintasi konteks dan ruang belajar baru yang selalu berubah. Pemahaman dan pengetahuan bagaimana memanfaatkan kehidupan sehari-hari sebagai ruang belajar. Oleh karena itu, perlu dinyatakan secara eksplisit bahwa m-Learning tidak selalu mengenai teknologi (Pachler, Bachamair, \& Cook, 2009, p.6).

Kepemilikan dan penggunaan smartphone di masyarakat dari berbagai kalangan dan usia sangat luas. Penggunaan smartphone selain sebagai alat komunikasi digunakan untuk mengakses berita, hiburan, dan penggunaan sosialmedia. Smartphone banyak beredar di pasaran dengan beragam pilihan, fitur dan teknologi selalu mengalami perkembangan, canggih dan harga terjangkau. m-Learning memiliki beberapa kelebihan (Sarrab, Elgamel, \& Aldabbas, 2012, p.34), penggunaan $m$-Learning memungkinkan praktisi pendidikan, guru, dan peserta didik untuk melampaui batas ruang sekolah tradisional (ruang kelas, ruang tutorial, laboratorium, dan ruang multimedia), meningkatkan fleksibilitas dan menawarkan kesempatan interaksi yang baru. Selain itu, m-Learning juga mendukung pembelajaran jarak jauh, meningkatkan pembelajaran yang berpusat pada keaktifan kegiatan belajar peserta didik (student- 
centered learning), mendukung keragaman kebutuhan belajar peserta didik dan pembelajaran individual.

Hasil survey terbatas mengenai analisis kebutuhan yang dilakukan di SMA N 1 Sentolo dan SMA N 1 Temon, diketahui bahwa sebagian besar peserta didik (99\%) menyukai pembelajaran biologi, akan tetapi masih merasa kesulitan dalam mempelajari biologi. Permasalahan dalam pembelajaran berupa kesulitan yang dihadapi tersebut diantaranya peserta didik menganggap cakupan pokok bahasan pembelajaran biologi yang cukup luas dan banyak, penggunaan istilah asing seperti bahasa latin sehingga peserta didik menganggap biologi sebagai suatu mata pelajaran hafalan. Selain persoalan tersebut, terdapat beberapa pokok bahasan yang dianggap sulit untuk dipelajari oleh peserta didik. Hasil data survey analisis kebutuhan juga menunjukkan bahwa sebanyak $99 \%$ peserta didik merasa masih membutuhkan bahan ajar lain yang dapat digunakan dalam membantu dalam mengarahkan kegiatan proses pembelajaran.

Salah satu tujuan pembelajaran sains adalah bagaimana mengajarkan sains melalui sebuah proses. Oakes (1997, p.33) menyatakan bahwa salah satu pendekatan untuk mempelajari sains sebagai sebuah proses adalah melalui metode pembelajaran discovery. Kelebihan metode pembelajaran ini, selain menyediakan tahapan yang perlu diikuti oleh peserta didik, juga mendorong peserta didik untuk berpikir melalui beberapa tahapan perkembangan mental seperti seorang peneliti dalam memecahkan permasalahan dalam penelitian. Dengan pengintegrasian Guided Discovery dengan syntax ExplorationConcept Invention-Discover dalam m-Learning, pada tahapan pembelajaran Exploration dan Concept Invention diharapkan terjadi peningkatan penguasaan kompetensi dasar dalam Kurikulum 2013, khususnya pada kompetensi keterampilan peserta didik, lalu pada tahapan Discover peserta didik memahami konsep hasil pengonstruksian materi pembelajaran yang diperoleh sehingga terjadi peningkatan pada kompetensi pengetahuan, utamanya pada kemampuan mengingat, hingga menganalisis.

Biologi sebagai salah satu alat pembelajaran dan mengembangkan diri diharapkan mampu untuk memaksimalkan potensi yang dimiliki oleh peserta didik di sekolah. Dalam tema persoalan yang dikaji Biologi yang tercantum dalam BSCS disebutkan salah satunya adalah "Sains sebagai proses penemuan" amat disayangkan jika peserta didik menganggap biologi merupakan pelajaran hafalan.

Lokasi lingkungan sekolah yang masih alami, dikelilingi dengan persawahan, kebun, kolam ikan, dan sungai dengan banyak potensi, akan lebih bermakna jika peserta didik melaksanakan pembelajaran dengan berinteraksi secara langsung di alam. Pembelajaran biologi pada pokok bahasan ekosistem akan lebih mudah dipelajari dan dipahami jika peserta didik langsung berhadapan dengan objek-objek biologi yang ada di alam. Menurut Odum (1998, p.14) satu cara terbaik untuk mulai mempelajari ekologi adalah dengan cara pergi ke luar dan mempelajari misalnya mengamati kolam kecil atau ke lapangan. Objek yang dipelajari peserta didik pada materi ekosistem itu nyata, dapat ditemui langsung oleh peserta didik, oleh karena itu diperlukan suatu panduan berbentuk lembar kerja peserta didik (LKPD) yang dikemas dalam bentuk $m$-Learning. LKPD $m$-Learning tersebut diharapkan dapat dimanfaatkan untuk memandu peserta didik selama mempelajari ekosistem di alam. LKPD dalam bentuk m-Learning mudah dibawa kemana saja dan kapan saja, memungkinkan peserta didik lebih fleksibel dalam memahami dan menemukan konsep, serta belajar dimana saja.

Penggunaan berbagai bahan ajar dan media pembelajaran berbentuk cetak yang selama ini digunakan sebetulnya sudah mampu membantu peserta didik dalam menemukan dan memahami konsep-konsep pembelajaran serta mewadahi berbagai bahan ajar, namun bentuknya yang cetak membuatnya menjadi kurang menarik, efisien, fleksibel, interaktif, terkadang tertinggal atau bahkan hilang, tidak mudah dibawa dan digunakan kapan saja. Untuk mengatasi kekurangan-kekurangan bahan ajar dan media pembelajaran cetak, perlu dikembangkan bentuk bahan ajar pembelajaran yang lain, salah satunya menggunakan aplikasi m-Learning melalui smartphone. Oleh karena itu peneliti bermaksud untuk mendesain dan mengembangkan produk berupa Lembar Kerja Peserta Didik (LKPD) m-Learning berbasis Guided Discovery pada pokok bahasan ekosistem untuk meningkatkan penguasaan Kompetensi Dasar (KD) dalam Kurikulum 2013. Pada LKPD mLearning, terdapat materi yang dapat menjadi sumber informasi dan data tentang ekosistem yang dapat dianalisis oleh peserta didik. Interaksi mahluk hidup yang terjadi dalam ekosistem juga tersedia dalam LKPD m-Learning tersebut sehingga ketersediaannya dapat membantu 
peserta didik untuk menguasai kompetensi dasar sesuai dengan tuntutan Kurikulum 2013.

Aplikasi LKPD Biologi m-Learning ini dikembangkan bertujuan untuk mengetahui kelayakan penggunaannya dalam proses pembelajaran di sekolah. Selain hal tersebut, tujuan penelitian ini adalah untuk mengetahui keefektifan dalam meningkatkan penguasaan kompetensi dasar dalam kurikulum 2013 oleh peserta didik sebagai pengguna aplikasi.

\section{METODE}

Penelitian ini merupakan penelitian pengembangan dengan model Design and Development Research (D \& D R). Design and Development Research adalah studi sistematis desain, pengembangan dan proses evaluasi dengan tujuan membangun dasar empiris untuk menciptakan produk yang instruksional dan noninstruksional untuk meningkatkan pengembangan alat dan model baru yang dikembangkan (Richey \& Klein, 2014, p.1).

Produk yang dikembangkan adalah suatu aplikasi Lembar Kerja Peserta Didik (LKPD). Aplikasi LKPD tersebut berbentuk mobile Learning yang diberi nama "ecoActivity". Pokok bahasan yang dikembangkan pada aplikasi adalah Ekosistem. Aplikasi LKPD mobile learning ini ditujukan untuk dapat digunakan bagi peserta didik kelas X SMA. Aplikasi ini dapat dimanfaatkan sebagai bahan ajar oleh guru dan peserta didik kelas X pada semester II (genap) dengan Kurikulum 2013. Prosedur dan tahapan pada penelitian Design and Development Research (D \& D R) ditampilkan pada Gambar 1.

Enam tahapan yang dilakukan pada penelitian ini yaitu (1) mengidentifikasi masalah (2) mendeskripsikan tujuan (3) mendesain dan mengembangkan artifak (4) menguji artifak (5) mengevaluasi hasil pengujian, dan (6) mengkomunikasikan hasil pengujian.

Pertama, tahapan pengidentifikasian masalah dilakukan survey untuk mengetahui permasalahan dan analisis kebutuhan peserta didik dan guru di lapangan. Untuk dapat mengembangkan produk yang dibutuhkan, peneliti melakukan survey terhadap guru dan peserta didik mengenai potensi yang dimiliki dan ada di sekolah serta mencari lebih banyak informasi mengenai hal-hal yang dibutuhkan oleh guru maupun peserta didik. Peneliti mendatangi sekolah-sekolah tujuan dan melakukan wawancara dengan guru Biologi. Wawancara dilakukan untuk mengetahui potensi yang dimiliki lingkungan sekolah dan kebutuhan yang diperlukan oleh guru dalam proses pembelajaran. Selain kegiatan wawancara, dilakukan juga pemberian angket terhadap peserta didik yang berisi tentang bagaimana kegiatan pembelajaran dan kebutuhan bahan ajar lain yang dibutuhkan sesuai penggunaan dan perkembangan teknologi saat ini.

Kedua, mendeskripsikan tujuan pengembangan. Produk dikembangkan dengan tujuan sebagai alat bantu dan bahan ajar dalam proses pembelajaran. Dalam proses pembelajaran, LKPD $m$-Learning dapat menjadi sumber informasi dan data tentang ekosistem sekaligus juga tentang interaksi yang terjadi dalam ekosistem sehingga membantu peserta didik menguasai kompetensi dasar yang disyaratkan oleh kurikulum. Meningkatkan efektivitas penggunaan teknologi oleh guru dan peserta didik dalam proses pembelajaran. Hal yang dilakukan sebelum mengembangkan produk adalah melakukan analisis kurikulum pembelajaran Biologi sesuai dengan kurikulum yang digunakan saat ini, yaitu Kurikulum 2013. Kemudian menganalisis tujuan pengembangan bahan ajar, dan menyusun peta kebutuhan LKPD Biologi yang akan dikembangkan.

Ketiga, mendesain dan mengembangkan artifak. Langkah ini merupakan tahapan perancangan dan pengembangan dan penentuan produk yang dikembangkan, yakni merancang aplikasi berupa LKPD m-Learning pada pokok bahasan Ekosistem, merancang instrumen untuk mengukur kelayakan, peningkatan penguasaan Kompetensi Dasar (KD) dalam Kurikulum 2013 (kompetensi pengetahuan dan keterampilan) penggunaan aplikasi LKPD m-Learning, serta merencanakan validitas dan reliabilitas instrumen yang digunakan.

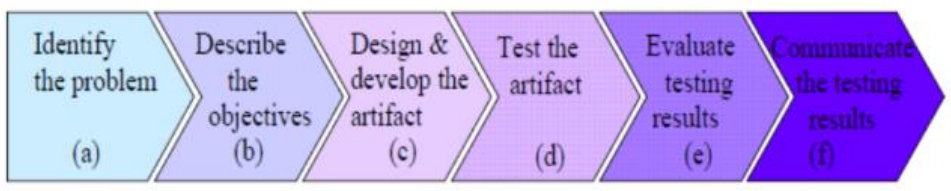

Gambar 1. Tahapan Penelitian Pengembangan Design and Development Research (Ellis \& Levy, 2010, p.111) 
Keempat, menguji artifak (produk). Pengujian produk yang dihasilkan, dilakukan oleh ahli media dan ahli materi Biologi, kemudian produk diuji oleh guru Biologi di sekolah, dan dilanjutkan pengujian di lapangan dengan pengguna aplikasi adalah peserta didik kelas X SMA. Serta dilakukan pengujian validitas dan reliabilitas terhadap instrumen yang digunakan

Kelima, setelah beberapa tahapan pengujian dilakukan kemudian mengevaluasi hasil pengujian, yang meliputi pengujian kelayakan aplikasi untuk digunakan sebagai media pembelajaran dan menganalisis hasil penguasaan kompetensi dasar (pengetahuan dan keterampilan) peserta didik kaitanya dengan penggunaan aplikasi LKPD m-Learning.

Keenam, tahapan terakhir yakni mengkomunikasikan hasil. Setelah dilakukan pengujian terhadap produk yang telah dihasilkan terhadap peserta didik di sekolah diperoleh saran dan masukan. Berdasarkan saran dan masukan tersebut, dilakukan perbaikan dan evaluasi berkaitan produk aplikasi yang dikembangkan. Perbaikan yang dilakukan meliputi semua aspek pada lembar penilaian antara lain pada aspek tampilan dan paparan materi. Setelah diperoleh semua data, baik hasil uji coba, evaluasi, dan revisi maka perlu dilakukan pengkomunikasian hasil yang diperoleh. Pengkomunikasian berbentuk laporan penelitian diberikan kepada pihak sekolah dan perguruan tinggi.

Pengujian produk LKPD m-Learning dilakukan pada bulan Maret hingga Mei 2017 di dua sekolah yang berada di wilayah Kabupaten Kulon Progo, yakni SMA Negeri 1 Sentolo dan SMA 1 Temon. Subjek coba (responden) pada penelitian ini adalah dosen ahli, teman sejawat, guru biologi dan peserta didik SMA $1 \mathrm{~N}$ Sentolo dan SMA N 1 Temon. Uji coba lapangan dilakukan pada peserta didik kelas X MIA2 dan X MIA3 dari SMA 1 Sentolo serta kelas X MIA1 dan X MIA2 dari SMA 1 Temon Kabupaten Kulon Progo sebanyak 126 peserta didik. pada masing-masing sekolah terdiri dua kelas yang satu kelas sebagai kelas eksperimen dan kelas lainnya sebagai kelas kontrol.

Uji coba untuk mengetahui keefektifan penggunaan produk aplikasi LKPD $m$-Learning dilakukan dengan kuasi eksperimen desain nonrandomized control group pretest-posttest design. Desain penelitian uji coba lapangan dapat dilihat pada Tabel 1.

Data yang diperoleh merupakan data kualitatif dan kuantitatif. Data kualitatif diperoleh dari hasil angket penilaian kelayakan produk
LKPD m-Learning oleh dosen ahli media, ahli materi, guru dan peserta didik. Dari data tersebut akan diketahui tingkat kelayakan produk sebagai media \& bahan ajar. Data kuantitatif yang diperoleh untuk mengetahui keefektifan produk LKPD m-Learning berupa nilai pretest dan posttest penguasaan kompetensi dasar peserta didik.

Tabel 1. Desain Penelitian Nonrandomized Control Group Pretest-Posttest Design

\begin{tabular}{lccc}
\hline Kelas & Pretest & Perlakuan & Posttes \\
\hline Eksperimen & $\mathrm{O}_{11}$ & $\mathrm{X}$ & $\mathrm{O}_{12}$ \\
Kontrol & $\mathrm{O}_{21}$ & $\mathrm{Y}$ & $\mathrm{O}_{22}$ \\
\hline
\end{tabular}

Keterangan:

$\mathrm{O}_{11} \quad$ : Hasil pretest peserta didik kelas eksperimen

$\mathrm{O}_{21} \quad$ : Hasil pretest peserta didik kelas kontrol

$\mathrm{X}$ : Perlakuan dengan menggunakan LKPD $m$ learning

$\mathrm{Y}$ : Perlakuan tanpa menggunakan LKPD $m$ Learning

$\mathrm{O}_{12}$ : Hasil posttest peserta didik kelas eksperimen

$\mathrm{O}_{22}$ : Hasil posttest peserta didik kelas kontrol

Instrumen pengumpulan data dalam penelitian ini menggunakan: (1) lembar angket kelayakan oleh ahli materi pendidikan biologi, ahli media pembelajaran, guru biologi, dan teman sejawat, (2) lembar tanggapan peserta didik, (3) lembar observasi penguasaan kompetensi keterampilan, dan (4) tes kognitif penguasaan kompetensi dasar (pengetahuan)

Instrumen tes disusun berdasarkan kisikisi indikator penguasaan Kompetensi Dasar sesuai dengan Kurikulum 2013 yang telah divalidasi (validitas konstruk \& validitas isi), face validity, dan validitas empiris menggunakan program QUEST. Dengan program QUEST dapat ditetapkan apakah suatu item atau testi/case/person dinyatakan fit dengan model. Uji validitas mengacu pada kriteria Infit Mean Square (MNSQ), dengan kriteria penerimaan berdasarkan Infit Mean Square (MNSQ) dengan kisaran 0,77-1,30. Reliabilitas juga dilakukan dengan program QUEST mengacu pada internal consistency dengan memperhatikan hasil pada bagian summary of case estimate dan summary of item estimates (Subali, 2016, p.139).

Teknik pengumpulan data yang digunakan terdiri dari teknik non tes dan tes. Teknik non tes, penggunaan angket yang digunakan untuk memperoleh data kelayakan dan lembar observasi untuk menilai kompetensi keterampilan. Teknik tes digunakan mengukur penguasaan kompetensi dasar (pengetahuan) peserta didik.

Teknik analisis deskriptif digunakan untuk memberikan gambaran informasi umum 
mengenai hasil analisis penilaian kelayakan. Analisis kelayakan produk hasil penelitian ini terdiri atas kelayakan media dan kelayakan materi yang diperoleh dengan validasi oleh ahli media, ahli materi biologi, dan tanggapan dari guru dan peserta didik. Kriteria kelayakan media produk yang dikembangkan dianalisis dengan tujuan untuk mengetahui kelayakan secara kualitas maupun kuantitas.

Kriteria kualitas produk pada penelitian ini meliputi 4 aspek, yaitu: (1) kualitas tampilan, (2) kemudahan pengoperasian, (3) kehandalan, (4) bahasa (keterbacaan). Kriteria kelayakan materi di dalam media, antara lain: (1) materi, (2) penyajian, (3) kesesuaian alat evaluasi, (4) bahasa (keterbacaan), dan (5) kualitas tampilan.

Hasil yang diperoleh, kemudian dikonversi dengan menggunakan tabel pengubahan skor penilaian ideal terhadap kriteria yang tercantum pada Tabel 2.

Tabel 2. Konversi Skor Penilaian Ideal terhadap Kriteria

\begin{tabular}{ccc}
\hline Rentang Skor & $\begin{array}{c}\text { Rentang } \\
\text { Skor }\end{array}$ & Kriteria \\
\hline $\mathrm{M}_{\mathrm{i}}+1,5 \mathrm{SD}_{\mathrm{i}}<\mathrm{X}$ & $3,25<\mathrm{X}$ & Sangat \\
$\mathrm{M}_{\mathrm{i}}+0,5 \mathrm{SD}_{\mathrm{i}}<\mathrm{X} \leq \mathrm{M}_{\mathrm{i}}+1,5$ & $2,75<\mathrm{X} \leq$ & Baik \\
$\mathrm{SD}_{\mathrm{i}}$ & 3,25 & Baik \\
$\mathrm{M}_{\mathrm{i}}-0,5 \mathrm{SD}_{\mathrm{i}}<\mathrm{X} \leq \mathrm{M}_{\mathrm{i}}+0,5$ & $2,25<\mathrm{X} \leq$ & Cukup \\
$\mathrm{SD}_{\mathrm{i}}$ & 2,75 & \\
$\mathrm{M}_{\mathrm{i}}-1,5 \mathrm{SD}_{\mathrm{i}}<\mathrm{X} \leq \mathrm{M}_{\mathrm{i}}-0,5$ & $1,75<\mathrm{X} \leq$ & Kurang \\
$\mathrm{SD}_{\mathrm{i}}$ & 2,25 & Sangat \\
$\mathrm{X} \leq \mathrm{M}_{\mathrm{i}}-1,5 \mathrm{SD}_{\mathrm{i}}$ & $\mathrm{X} \leq 1,75$ & Kurang \\
\hline
\end{tabular}

Teknik analisis statistik inferensial dalam penelitian ini digunakan untuk melakukan uji hipotesis statistik dengan menggunakaan: (1) uji prasyarat, meliputi uji normalitas, uji homogenitas, dan uji-t untuk mengetahui kondisi kemampuan awal antara peserta didik kelas kontrol dan kelas eksperimen dan (2) uji hipotesis menggunakan uji Anakova untuk mengetahui keefektifan penggunaan LKPD $m$ Learning berbasis Guided Discovery dalam meningkatkan penguasaan Kompetensi Dasar (KD) peserta didik sesuai dengan Kurikulum 2013 pada pokok bahasan Ekosistem.

\section{HASIL DAN PEMBAHASAN}

Fokus penelitian ini adalah untuk mendesain dan mengembangkan produk aplikasi Lembar Kerja (LKPD) m-Learning. berbasis Guided Discovery pada pokok bahasan ekosistem untuk kelas X SMA semester genap. Pengembangan produk dilaksanakan sesuai prosedur penelitian pengembangan Design and Development (D \& D R). Data yang diperoleh penelitian mengenai kelayakan disajikan pada tabel hasil penilaian kelayakan yang dihimpun dari angket yang diisi oleh dosen ahli, guru biologi, rekan sejawat, dan 126 peserta didik.

\section{Pengujian dan Penilaian Kelayakan Produk oleh Ahli Media Pembelajaran dan Ahli Materi Pembelajaran Biologi}

$m$-Learning adalah pembelajaran dengan jarak jauh maupun dekat yang tidak terbatas ruang dan lintas waktu dengan memanfaatkan perangkat komputasi yang berukuran kecil dan dapat dibawa kemana saja dan kapan saja. Dalam m-Learning terdapat komponen penting yang dapat digunakan peserta didik untuk belajar, diantaranya pengantar kegiatan pembelajaran, ringkasan materi, tahapan kegiatan belajar peserta didik, soal kuis interaktif, dan media pembelajaran dapat ditambahkan didalamnya. Produk yang dikembangkan berupa aplikasi LKPD m-Learning berbasis Guided Discovery pada pokok bahasan ekosistem diuji dan dinilai kelayakannya oleh ahli yang memiliki kompetensi di bidangnya. Hasil penilaian kelayakan disajikan pada Tabel 3.

Tabel 3. Hasil Penilaian Kelayakan Produk oleh Ahli Materi Pembelajaran Biologi

\begin{tabular}{|c|c|c|c|}
\hline Aspek Penilaian & & Skor & Keterangan \\
\hline Materi & & 3,00 & Baik \\
\hline Penyajian & & 3,14 & Baik \\
\hline $\begin{array}{l}\text { Kesesuaian dengan } \\
\text { Evaluasi }\end{array}$ & Alat & 3,00 & Baik \\
\hline Bahasa (Keterbacaan) & & 3,14 & Baik \\
\hline Tampilan & & 3,14 & Baik \\
\hline Rata-rata & & 3,13 & Baik \\
\hline
\end{tabular}

Tabel 3 menunjukkan bahwa penilaian kelayakan oleh ahli materi pembelajaran biologi pada keseluruhan aspek diperoleh skor rata-rata 3,13 sehingga diketahui, produk LKPD $\mathrm{m}$ Learning berbasis Guided Discovery yang dihasilkan termasuk dalam kategori baik dan layak untuk digunakan dalam proses pembelajaran biologi khususnya pada pokok bahasan ekosistem. Penilaian juga dilakukan oleh ahli media pembelajaran seperti disajikan pada Tabel 4.

Berdasarkan hasil penilaian produk LKPD $m$-Learning oleh ahli media pembelajaran ditinjau sebagai media dalam teknologi pendidikan diperoleh hasil bahwa aplikasi yang dirancang dan dikembangkan termasuk kategori baik, dengan rata-rata keseluruhan aspek penilaian sebesar 3,03. Hal ini berarti bahwa LKPD $m$ - 
Learning berbasis Guided Discovery secara teknologi media pembelajaran berdasarkan aspek tampilan, kemudahan pengoperasian, kehandalan, dan bahasa termasuk dalam kategori baik dan dinyatakan layak untuk digunakan untuk membantu pelaksanaan proses pembelajaran dan sesuai dengan kebutuhan peserta didik.

Tabel 4. Hasil Penilaian Kelayakan Produk oleh Ahli Media Pembelajaran

\begin{tabular}{llc}
\hline Aspek Penilaian & Skor & Keterangan \\
\hline Tampilan & 3,14 & Baik \\
Kemudahan Pengoperasian & 3,00 & Baik \\
Kehandalan & 3,00 & Baik \\
Bahasa (Keterbacaan) & 3,00 & Baik \\
Rata-rata & $\mathbf{3 , 0 3}$ & Baik \\
\hline
\end{tabular}

\section{Pengujian dan Pendapat Kelayakan Produk oleh Guru Biologi dan Teman Sejawat}

Tabel 5. Hasil Pendapat Kelayakan Produk oleh Guru Biologi

\begin{tabular}{lcc}
\hline \multicolumn{1}{c}{ Aspek } & Rata-rata & Keterangan \\
\hline Materi & 3,75 & Sangat Baik \\
Penyajian & 3,78 & Sangat Baik \\
$\begin{array}{l}\text { Kesesuaian dg Alat } \\
\text { Evaluasi }\end{array}$ & 3,66 & Sangat Baik \\
$\begin{array}{l}\text { Bahasa (Keterbacaan) } \\
\text { Tampilan }\end{array}$ & 4,00 & Sangat Baik \\
$\begin{array}{l}\text { Kemudahan } \\
\text { Pengoperasian }\end{array}$ & 3,57 & Sangat Baik \\
$\begin{array}{l}\text { Kehandalan } \\
\text { Rata-rata }\end{array}$ & 3,50 & Sangat Baik \\
& 3,50 & Sangat Baik \\
& $\mathbf{3 , 6 8}$ & Sangat \\
Baik
\end{tabular}

Tabel 6. Hasil Pendapat Kelayakan Produk oleh Teman Sejawat

\begin{tabular}{lcc}
\hline \multicolumn{1}{c}{ Aspek } & Rata-rata & Keterangan \\
\hline Materi & 3,16 & Baik \\
Penyajian & 3,38 & Sangat Baik \\
Kesesuaian dg Alat & & Baik \\
Evaluasi & 3,11 & \\
Bahasa (Keterbacaan) & 3,66 & Sangat Baik \\
Tampilan & 3,52 & Sangat Baik \\
Rata-Rata & & Sangat \\
& $\mathbf{3 , 3 6}$ & Baik \\
\hline
\end{tabular}

Selain penilaian kelayakan yang dilakukan oleh para ahli, produk juga diuji dan diberi pendapat oleh guru dan teman sejawat. Guru dan teman sejawat memberikan masukan dan saran mengenai beberapa aspek yang dikembangkan dalam aplikasi. Masukan dan saran yang diberikan akan sangat membantu dalam perbaikan dan kualitas produk yang dihasilkan. Hasil dari pengujian dan pendapat mengenai kegunaan produk aplikasi LKPD m-Learning berbasis
Guided Discovery disajikan pada Tabel 5 dan Tabel 6.

Berdasarkan Tabel 5 mengenai pengujian dan kelayakan produk aplikasi LKPD m-Learning berbasis Guided Discovery oleh guru diperoleh skor rata-rata pada keseluruhan aspek sebesar 3,68. Pada Tabel 6 analisis kelayakan oleh teman sejawat diperoleh nilai rata-rata sebesar 3,36. Sehingga berdasarkan pendapat kelayakan produk oleh Guru dan Teman Sejawat termasuk dalam kategori sangat baik di seluruh aspek. Dengan pemberian pendapat kelayakan produk meliputi aspek materi, penyajian, kesesuaian alat evaluasi, bahasa, kemudahan pengoperasian, serta kehandalan produk saat digunakan dalam proses pembelajaran.

\section{Respon Penggunaan Produk oleh Peserta Didik}

Data mengenai respon penggunaan produk diperoleh melalui kegiatan pengujian dengan subjek coba adalah peserta didik. Peserta didik menggunakan aplikasi dalam proses pembelajaran. Setelah itu peserta didik dimintai pendapat dan respon mengenai kualitas aplikasi yang sudah digunakan. Respon dan pendapat dituliskan oleh peserta didik dalam lembar angket respon. Berdasarkan pengujian yang telah dilakukan, diperoleh respon peserta didik mengenai produk yang ditabulasikan pada Tabel 7.

Tabel 7. Respon Penggunaan Produk oleh Peserta Didik

\begin{tabular}{lcl}
\hline \multicolumn{1}{c}{ Aspek } & Rata-rata & Keterangan \\
\hline Bahasa (Keterbacaan) & 3,37 & Sangat Baik \\
Tampilan & 3,28 & Sangat Baik \\
Kemudahan Pengoperasian & 3,32 & Sangat Baik \\
Kehandalan & 3,18 & Baik \\
Rata-rata & $\mathbf{3 , 2 9}$ & Sangat Baik \\
\hline
\end{tabular}

Hasil respon tanggapan peserta didik terhadap kegunaan aplikasi LKPD m-Learning berbasis Guided Discavory dalam proses pembelajaran diperoleh data bahwa pada aspek bahasa, tampilan, kemudahan pengoperasian, dan kehandalan memperoleh skor rata-rata 3,29 dengan kategori sangat baik. Pada aspek keterbacaan dengan skor rata-rata yang diberikan peserta didik $(3,37)$, aspek tampilan $(3,28)$, kemudahan pengoperasian $(3,32)$, hanya pada aspek kehandalan diperoleh skor rata-rata 3,18, sehingga termasuk dalam kategori baik. Hal ini berarti dalam penggunaan dan penerapan di dalam proses pembelajaran dapat berjalan dengan baik dan mendukung kegiatan yang dilakukan oleh peserta didik, 


\section{Hasil Analisis Keefektifan LKPD M-Learning Berbasis Guided Discovery terhadap Pengua- saan Kompetensi Dasar (KD) Pokok Bahasan Ekosistem dalam Kurikulum 2013}

Berdasarkan Peraturan Pemerintah tahun 2016 Nomor 24 pada Bab I Pasal 1 dinyatakan bahwa "Kurikulum 2013 pada pendidikan dasar dan pendidikan menengah mencakup Sekolah Dasar/Madrasah Ibtidaiyah (SD/MI), Sekolah Menengah Pertama/Madrasah Tsanawiyah (SMP/MTs), Sekolah Menengah Atas/Madrasah Aliyah (SMA/MA), dan Sekolah Menengah Kejuruan/Madrasah Aliyah Kejuruan (SMK/ MAK)." Sehingga saat ini kurikulum yang digunakan di sekolah sudah mengacu pada Kurikulum 2013. Penggunaan kurikulum 2013 dimaksudkan agar peserta didik memiliki kompetensi di segala hal, tidak hanya pada kemampuan kognitif atau pengetahuan saja, akan tetapi pada kompetensi yang lain yang meliputi kompetensi spiritual, sosial, dan keterampilan.

Pada Bab II pasal 2 dinyatakan bahwa “(1) Kompetensi inti pada Kurikulum 2013 merupakan tingkat kemampuan untuk mencapai standar kompetensi lulusan yang harus dimiliki seorang peserta didik pada setiap tingkat kelas. (2) Kompetensi dasar merupakan kemampuan dan materi pembelajaran minimal yang harus dicapai peserta didik untuk suatu mata pelajaran pada masing-masing satuan pendidikan yang mengacu pada kompetensi inti. (4) Kompetensi dasar pada kurikulum 2013 berisi kemampuan dan materi pembelajaran untuk suatu mata pelajaran pada masing-masing satuan pendidikan yang mengacu pada kompetensi inti. (5) Kompetensi inti dan kompetensi dasar digunakan sebagai dasar untuk perubahan buku teks pelajaran pada pendidikan dasar dan pendidikan menengah."

Penelitian ini dilakukan dengan tujuan untuk mengembangkan dan menghasilkan produk berupa aplikasi bahan ajar berbentuk LKPD $m$ Learning pada pokok bahasan ekosistem. LKPD yang dikembangkan berbasis Guided Discovery, sehingga kegiatan-kegiatan yang dirancang dalam aplikasi LKPD Biologi mobile Learning sesuai dengan syntax pembelajaran Guided Discovery. LKPD yang dikembangkan terdiri atas tiga pokok bahasan utama sesuai dengan Kompetensi Inti dan Kompetensi Dasar pada Kurikukulum 2013 yang dikemas dalam kegiatan "ecoActivity" I, II, dan III yang mencakup pokok bahasan Komponen Penyusun Ekosistem, Aliran Energi \& Interaksi antar komponen
Penyusun Ekosistem, dan Daur Biogeokimia. Setiap pokok bahasan peserta didik belajar secara aktif dengan panduan yang disusun pada aplikasi LKPD $m$-Learning. Setiap kegiatan per pokok bahasan dalam LKPD ini terdiri atas Topik Pembelajaran, Tujuan Kegiatan, Pendahuluan sebagai pengantar dalam kegiatan pembelajaran, serangkaian tahapan kegiatan yang terdiri atas Objek Pengamatan, Alat \& Bahan, Langkah Kerja, Lembar Data Hasil Pengamatan, dan Diskusi. Handziko \& Suyanto (2015, p 213) Contoh objek biologi hendaknya berasal dari area lokal sehingga mahasiswa (peserta didik) pun merasa dekat dan memiliki rasa kepemilikan dengan proses biologi yang terjadi. Dengan panduan kegiatan-kegiatan tersebut diharapkan peserta didik memiliki pengalaman belajar langsung di alam, menemui objek nyata Biologi, sehingga mampu mengembangkan kompetensi keterampilan dan keterampilan proses seperti yang diharapkan sebagai hasil belajar sains Biologi.

Selain kegiatan-kegiatan yang dirancang untuk dapat memandu peserta didik menemukan konsep pada materi pokok Ekosistem, pada aplikasi ini juga terdapat glosarium "ecoGlosarium" yang membantu peserta didik untuk mencari makna mengenai istilah-istilah Biologi yang sulit, dan juga tersedia menu "ecoExercise" yang berisi soal-soal latihan interaktif pada materi ekosistem. Hasil latihan pada menu ecoExercise dapat diketahui langsung oleh peserta didik melalui aplikasi ini, sehingga peserta didik dapat mengetahui apa yang sudah mereka kuasai dan pahami selama mempelajari pokok bahasan Ekosistem.

Pengujian produk dilakukan pada dua SMA Negeri di Kabupaten Kulonprogo, yaitu SMA N 1 Sentolo dan SMA N 1 Temon. Pelaksanaan pengujian produk dilakukan tiap sekolah selama tiga jam x 3 pertemuan. Pertemuan pertama peserta didik melakukan tes kemampuan awal (pretest) dan melakukan kegiatan pengamatan komponen penyusun ekosistem dan interaksi antar makhluk hidup di lapangan dengan panduan produk LKPD model $m$ Learning berbasis Guided Discovery. Pada pertemuan kedua peserta didik mengumpulkan laporan, melakukan presentasi hasil pengamatan yang sudah dilakukan dan dilanjutkan melakukan diskusi pada pokok bahasan daur Biogeokimia untuk dapat menemukan dan mengkonstruk konsep. Pada pertemuan ketiga, yang merupakan pertemuan terakhir peserta didik melakukan presentasi hasil diskusi mengenai 
pokok bahasan daur Biogeokimia dan ditutup dengan tes kemampuan akhir (posttest). Selama pelaksanaan pembelajaran berlangsung peneliti dan guru mengamati keterampilan dan menilai peserta didik menggunakan lembar observasi.

Dalam pengujian di lapangan, mulai dari proses instalasi aplikasi dan penggunaan dilakukan sendiri oleh peserta didik tanpa bantuan guru maupun peneliti, karena peserta didik sebagian besar memiliki dan dapat mengoperasikan smartphone dengan baik. Dari pengujian ini terlihat peserta didik tidak menemui kendala yang berarti selama mengoperasikan aplikasi LKPD Biologi m-Learning pada smartphone.

\section{Uji Prasyarat}

Pada pengujian keefektifan penggunaan produk LKPD m-Learning berbasis Guided Discovery pengaruhnya terhadap penguasaan Kompetensi Dasar (KD) peserta didik dalam Kurikulum 2013 pokok bahasan ekosistem, terlebih dahulu dilakukan uji prasyarat yang meliputi Uji Homogenitas, Uji Normalitas, dan Uji Beda Kemampuan Awal Peserta Didik. Ringkasan hasil uji prasyarat yang dilakukan tersaji pada Tabel 8.

Hasil uji normalitas dengan KolmogorovSmirnov test yang telah dilakukan menggunakan program SPSS dengan taraf kesalahan 0,05 diketahui bahwa kelas kontrol memiliki nilai signifikansi (Sig.) sebesar 0,082 dan kelas eksperimen memiliki nilai signifikansi (Sig.) sebesar 0,042. Berdasarkan syarat pengambilan keputusan (Sig.) > 0,05 maka diketahui bahwa data kelas kontrol terdistribusi normal karena nilai signifikansinya (Sig.) sebesar 0,082 lebih besar dari $0,05(0,082>0,05)$, namun pada kelas eksperiman diperoleh nilai signifikansi (Sig.) sebesar 0,045 yang nilaianya lebih kecil dari
$0,05(0,045<0,05)$, maka disimpulkan pada kelas eksperimen tidak terdistribusi normal.

Hasil uji homogenitas terpenuhi apabila nilai Sig. dari hasil Levene's Test lebih besar dari taraf kesalahan $(0,05)$ yang ditetapkan. Berdasarkan pengujian yang dilakukan menggunakan program SPSS diperoleh hasil nilai signifikansi (Sig.) sebesar 0,554 dimana nilainya lebih besar dari $0,05(0,554>0,05)$. Maka berdasarkan uji tersebut diketahui bahwa kelas kontrol dan kelas eksperimen mempunyai varians yang sama atau homogen.

Untuk mengetahui apakah kondisi kemampuan awal peserta didik kelas kontrol dan kelas eksperimen memiliki varian yang sama, dilakukan uji t pada hasil pretest yang telah dilakukan peserta didik kelas kontrol maupun kelas eksperimen. Berdasarkan perhitungan diperoleh nilai $\mathrm{t}$ hitung $=-2,456$ dengan $\mathrm{df}=$ 124, jika dibandingkan dengan $t$ tabel yang diketahui dengan menggunakan tabel statistik pada signifikansi 0,05: 2 (uji 2 sisi) dengan derajat kebebasan $(\mathrm{df})=\mathrm{n}-2$, atau $126-2=124$, diketahui besarnya $\mathrm{t}$ tabel adalah 1,980. Maka $\mathrm{t}$ hitung sebesar $-2.456<\mathrm{t}$ tabel sebesar $-1,980$, disimpulkan berdasarkan ketentuan pengambilan keputusan uji t, Ho ditolak, sehingga terdapat perbedaan nilai hasil pretest kemampuan awal penguasaan kompetensi dasar kurikulum 2013 peserta didik kelas kontrol dan kelas eksperimen. Selain itu, dengan menggunakan perbandingan sig. (2-tailed) yang memiliki nilai 0.015 yang memiliki nilai lebih kecil daripada alpha (0.05), dapat diketahui antara kelas kontrol dan kelas eksperimen berdasarkan analisis uji t pada pretes memiliki hasil varians yang tidak sama (berbeda). Oleh karena kedua hal tersebut, maka analisis data selanjutnya harus dilakukan dengan uji Anacova.

Tabel 8. Ringkasan Hasil Uji Prasyarat

\begin{tabular}{lcccl}
\hline \multicolumn{1}{c}{ Uji } & Subjek Coba (Kelas) & Hasil & Sig. & \multicolumn{1}{c}{ Ket } \\
\hline Normalitas & Kontrol & 0,082 & $>0,05$ & Terdistribusi normal \\
& Eksperimen & 0,042 & $>0,05$ & Tidak terdistribusi normal \\
Homogenitas & Kontrol \& Eksperimen & 0,554 & $>0,05$ & Homogen \\
Beda (uji - t) & Kontrol \& Eksperimen & $-2.456<-1,980$ & -t hitung $\geq-$ t tabel & Terdapat perbedaan \\
Kemampuan Awal & & 0.015 & $>0,05$ & kondisi kemampuan awal \\
\hline
\end{tabular}

Tabel 9. Hasil Uji Anacova Kefektifan Penggunaan Aplikasi LKPD m-Learning Berbasis Guided Discovery terhadap Penguasaan Kompetensi Dasar (Kompetensi Pengetahuan)

\begin{tabular}{lccc}
\hline \multicolumn{1}{c}{ Sumber Variansi } & Hasil & Sig. & Keterangan \\
\hline Corrected Model & 0,000 & 0,05 & $<0,05$, Ho ditolak \& Ha diterima \\
Pretes & 0,000 & 0,05 & $<0,05$, Ho ditolak \& Ha diterima \\
Kelas Kontrol \& Kelas Eksperimen & 0,000 & 0,05 & $<0,05$, Ho ditolak \& Ha diterima \\
\hline
\end{tabular}




\section{Peningkatan Penguasaan Kompetensi Dasar (Pengetahuan) dalam Kurikulum 2013}

Analisis kovarian (Anacova) dilakukan berdasarkan hasil yang diperoleh dari uji prasyarat. Anacova ini dilakukan untuk mengetahui peningkatan penguasaan kompetensi pengetahuan berdasarkan varian penggunaan aplikasi LKPD $m$-Learning berbasis Guided Discovery atau dari pengaruh kemampuan awal yang dimiliki peserta didik. Hasil uji Anacova yang dilakukan disajikan pada Tabel 9.

Hasil uji Anacova yang dilakukan menunjukkan bahwa nilai signifikansi pada kelas kontrol dan kelas eksperimen sebesar 0,000. Besarnya signifikansi $<0,05(0,000<0,05)$ maka Ho ditolak, sehingga Ha diterima, hal ini berarti secara signifikan dapat disimpulkan bahwa rata-rata nilai hasil posttest penguasaan kompetensi dasar (pengetahuan) kurikulum 2013 peserta didik kelas eksperimen lebih tinggi daripada kelas kontrol.

Jika dilihat angka signifikansi pretes sebagai kovariat sebesar 0,000, karena Sig. $<0,05$ hal ini berarti terdapat pengaruh kovariat pretest terhadap hasil posttest peserta didik. Sehingga diketahui dengan tingkat kepercayaan 95\% terdapat hubungan antara hasil pretest dengan hasil poststest yang diperoleh oleh peserta didik.

Kemudian untuk pengaruh perlakuan yang diberikan terhadap peserta didik diperoleh angka signifikansi sebesar 0,000 dengan Sig. 0,05 . karena nilainya di bawah 0,05 maka diketahui bahwa tanpa pengaruh kovarian pretest, pada tingkat kepercayaan $95 \%$ terdapat pengaruh perlakuan penggunaan aplikasi LKPD $m$ Learning terhadap posttest hasil belajar kognitif peserta didik.

Pengambilan keputusan tersebut diperkuat dengan data persentase peningkatan antara kelas kelas kontrol dan kelas eksperimen yang disajikan secara ringkas pada Tabel 10.

Tabel 10. Persentase Peningkatan Penguasaan Kompetensi Pengetahuan

\begin{tabular}{lcccc}
\hline & \multicolumn{2}{c}{ Nilai Penguasaan KD Ekosistem } \\
\cline { 2 - 5 } & \multicolumn{2}{c}{ Kelas } & \multicolumn{2}{c}{ Kelas } \\
Kontrol & \multicolumn{2}{c}{ Eksperimen } \\
\cline { 2 - 5 } & Awal & Akhir & Awal & Akhir \\
\hline Tertinggi & 92 & 90 & 88 & 98 \\
Terendah & 24 & 50 & 30 & 34 \\
Rata-rata & 55,93 & 69,90 & 62,12 & 81,26 \\
Kenaikan & \multicolumn{2}{c}{$24,97 \%$} & $30,81 \%$ \\
Rata-rata (\%) & \multicolumn{3}{c}{30} \\
\hline
\end{tabular}

Dari data Tabel 10 terlihat pada peningkatan rata-rata nilai posttest dari pretest antara kelas kontrol dan kelas eksperimen. Peningkatan terlihat dari nilai rata-rata pretest kelas kontrol dari 55,93 menjadi 69,90 saat posttest dengan persentase kenaikan sebesar 24,97\%. Sedangkan pada kelas eksperimen terjadi peningkatan dari 62,12 saat pretest menjadi 81,26 saat posttest dengan persentase kenaikan sebesar 30,81\%. Berdasarkan data, diketahui bahwa setelah melakukan proses pembelajaran terdapat kenaikan nilai hasil penguasaan kompetensi keterampilan baik kelas kontrol maupun kelas eksperimen, dengan persentase kenaikan skor posttest kelas eksperimen lebih tinggi jika dibandingkan dengan kelas kontrol.

Selain data kenaikan skor pretest-posttest juga diperhatikan pada perolehan gain score peserta didik. Kriteria pengkategorian hasil gain score ditentukan oleh Hake (1999, p. 1) sebagai berikut, apabila besarnya nilai gain score (g) lebih besar dari 0,7 $(\mathrm{g}>0,7)$ maka termasuk dalam kategori tinggi, apabila nilai gain score berada di antara $0,3-0,7(0,7>\mathrm{g}>0,3)$ maka termasuk kategori sedang, dan apabila nilai $\mathrm{g}$ kurang dari $0,3(\mathrm{~g}<0,3)$ maka termasuk dalam kategori rendah. Diketahui data rata-rata gain score kelas eksperimen sebesar $(\mathbf{0 , 4 9 )}$ dan termasuk dalam kategori sedang lebih tinggi jika dibandingkan dengan nilai rata-rata gain score kelas kontrol yang lebih rendah $(\mathbf{0}, \mathbf{2 5})$ dan termasuk dalam kategori rendah.

Lee, et. al. (2002, p.35) menyatakan "metode pembelajaran konstruktivisme telah dilaporkan lebih efektif dalam meningkatkan pemahaman konsep biologi, keterampilan penalaran dan sikap positif terhadap sains pada tingkat perguruan tinggi dibandingkan model pembelajaran tradisional." As you teach science, provide learning experiences for your students by having them involved in discovering sciences concept for themself. This involved your careful planning and direction, so that the lesson go well and students are guided to the desired objectives and conclusions. That is why this text refers to this type learning as guided discovery learning/teaching (Sund \& Carin, 1989, p.46). Makna dari pernyataan tersebut adalah pembelajaran sains yang dirancang oleh guru dengan menyediakan pengalaman belajar (learning experiences) untuk peserta didik dengan membuat peserta didik ikut terlibat di dalam menemukan konsep sains secara mandiri. Proses ini melibatkan perencanaan dan pengarahan yang teliti, sehinggga pembelajaran dapat berjalan 
lancar dan peserta didik dibimbing untuk menemukan tujuan pembelajaran yang diharapkan dan menyimpulkannya. Jenis pembelajaran ini dikenal sebagai pembelajaran Guided discovery learning/teaching.

Peran dan tanggung jawab guru pada pembelajaran discovery adalah membantu peserta didik untuk melalui berbagai tahapan pengalaman belajar berkelanjutan, melibatkan peserta didik belajar dengan materi sains dan menantang peserta didik untuk merasionalkan apa yang hendak diperoleh dengan discovery melalui tulisan, studi pustaka, menguasai istilah sains, dan menyelenggarakan kegiatan lainnya yang dapat mengarahkan peserta didik untuk melakukan penemuan yang lebih banyak lagi (DeRosa, \& Abruscato, 2014, p.38). Pembelajaran guided discovery memfasilitasi dan mendukung peserta didik untuk mengetahui bagaimana caranya belajar (learn to learn) serta kaitanya dengan belajar sepanjang hayat (lifetime learning). Guided discovery membantu peserta didik mendapatkan pengetahuan secara unik dengan caranya sendiri karena mereka menemukannya sendiri. Guided discovery tidak terbatas untuk menemukan sesuatu yang sepenuhnya baru, namun berkaitan dengan menyusun kembali data sehingga peserta didik dapat berjalan/melangkah melewati melampaui data untuk membentuk konsep baru bagi peserta didik. Guided discovery melibatkan penemuan makna (finding the meaning), organization, dan struktur ide-ide (Sund \& Carin, 1989, p.94).

Sund \& Carin (1989, p.95) menyatakan "Jerome Bruner, seorang ahli yang berperan dalam pengembangan pembelajaran discovery, menguraikan empat alasan untuk menggunakan pendekatan guided discovery dalam pembelajaran, yaitu (1) potensi intelektual, (2) motivasi intrinsik daripada motivasi ekstrinsik, (3) belajar mengenal heuristik penemuan, dan konservasi memori."

Berdasarkan pemaparan tersebut maka dapat dinyatakan bahwa penggunaan produk aplikasi LKPD Biologi m-Learning berbasis Guided Discovery secara statistik efektif dapat meningkatkan hasil belajar kognitif peserta didik dan terdapat perbedaan peningkatan yang diperoleh kelas eksperimen lebih tinggi dibandingkan kelas kontrol. Hal ini serupa dengan hasil penelitian terlebih dahulu yang sudah dilakukan oleh Shieh \& Yu (2016) dengan judul "A Study on Information Technology Integrated Guided Discovery Introduction towards Students' Learning Achievement and Learning Retention" dengan hasil bahwa pembelajaran Guided Discovery mempengaruhi peningkatan pencapaian belajar peserta didik.

\section{Peningkatan Penguasaan Kompetensi Dasar (Keterampilan) dalam Kurikulum 2013}

Di dalam Kurikulum 2013 disyaratkan bahwa kompetensi yang harus dikuasai peserta didik tidak hanya pada ranah kognitif (pengetahuan), melainkan juga pada kompetensi keterampilan. Hasil analisis statistik skor kompetensi keterampilan peserta didik menggunakan uji Anakova disajikan pada Tabel 11.

Analisis varian berdasarkan Tabel 11. diketahui bahwa nilai signifikansi pada kelas kontrol dan kelas eksperimen sebesar 0,000. Besarnya signifikansi $<0,05(0,000<0,05)$ maka Ho ditolak, sehingga Ha diterima, hal ini berarti secara signifikan dapat disimpulkan bahwa rata-rata skor kompetensi keterampilan peserta didik kelas eksperimen lebih tinggi daripada kontrol.

Jika dilihat angka signifikansi kovariat sebagai pretest sebesar 0,146 karena Sig. $>0,05$ hal ini berarti bahwa tidak terdapat pengaruh kovariat pretes terhadap hasil skor keterampilan proses sains peserta didik. Sehingga diketahui dengan tingkat kepercayaan 95\% tidak terdapat hubungan antara hasil pretest dengan hasil posttest yang diperoleh oleh peserta didik.

Kemudian untuk pengaruh perlakuan yang diberikan terhadap peserta didik diperoleh angka signifikansi sebesar 0,000 dengan Sig. 0,05 karena nilainya di bawah 0,05 maka diketahui bahwa tanpa pengaruh kovarian pretest, pada tingkat kepercayaan $95 \%$ terdapat pengaruh perlakuan dengan penggunaan aplikasi LKPD m-Learning terhadap skor kompetensi keterampilan peserta didik.

Tabel 11. Hasil Uji Anacova Kefektifan Penggunaan Aplikasi LKPD m-Learning Berbasis Guided Discovery terhadap Penguasaan Kompetensi Dasar (Kompetensi Keterampilan)

\begin{tabular}{lccl}
\hline \multicolumn{1}{c}{ Sumber Variansi } & Hasil & Sig. & \multicolumn{1}{c}{ Ket. } \\
\hline Corrected Model & 0,000 & 0,05 & $<0,05$, Ho ditolak \& Ha diterima \\
Pretes & 0,146 & 0,05 & $>0,05$, Ho diterima \\
Kelas Kontrol \& Kelas Eksperimen & 0,000 & 0,05 & $<0,05$, Ho ditolak \& Ha diterima \\
\hline
\end{tabular}


Perbedaan tersebut dapat terlihat dari data hasil perbandingan skor total rata-rata kompetensi keterampilan kelas kontrol dan kelas eksperimen (Gambar 2.)

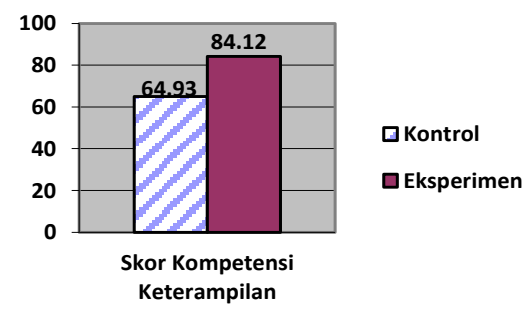

\section{Gambar 2. Skor Rata-rata Kompetensi Keterampilan}

Berdasarkan Gambar 2 diketahui bahwa skor total rata-rata kompetensi keterampilan proses kelas eksperimen lebih tinggi, yakni 84,12 dibandingkan dengan kelas kontrol yang memperoleh skor sebesar 64,93. Pemberian skor penguasaan kompetensi keterampilan proses dilakukan menggunakan lembar observasi. Penilaian dilakukan selama tiga kali pertemuan. Dari kegiatan penilaian yang dilakukan diperoleh data perbandingan skor rata-rata antara kelas kontrol dan kelas eksperimen pada tiap dimensi (Gambar 3.)

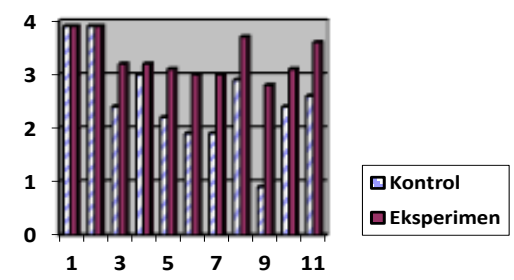

\section{Gambar 3. Skor Rata-rata Kompetensi Keterampilan Per Dimensi}

Hasil penguasaan kompetensi keterampilan per dimensi diketahui bahwa skor tertinggi pada dimensi kompetesi keterampilan adalah pada dimensi nomor 1 dan 2, sedangkan skor terendah terdapat pada dimensi nomor 9 baik pada kelas kontrol maupun kelas eksperimen.

Penilaian pada dimensi nomor 1 berkaitan dengan kegiatan dalam melakukan pengamatan (observasi). Hampir keseluruhan semua peserta didik kelas kontrol maupun eksperimen sudah dapat melakukan pengamatan dengan baik, Dimensi nomor 2 mengenai kegiatan pengklasifikasian atau pengelompokkan. Kelas kontrol maupun kelas eksperimen juga sudah dapat melakukan kegiatan pengklasifikasian dengan baik. Sedangkan, dimensi dengan skor terendah adalah nomor 9 dimensi keterampilan proses sains mengenai mendesain kegiatan penyelidikan termasuk kegiatan eksperimen indikator mengenai penggunaan alat bahan, pencatatan apa yang akan diukur, diamati dan dicatat sudah baik, namun beberapa peserta didik mengalami kebingungan dalam menentukan variabel penentu dan mendefinisikan variabel secara operasional.

Untuk dimensi-dimensi keterampilan proses yang lain, selain dimensi nomor 1, 2, dan 9 terlihat pada Gambar 4, hasil skor rata-rata yang diperoleh peserta didik kelas eksperimen lebih tinggi jika dibandingkan dengan hasil kelas kontrol. Hal ini dikarenakan dengan penggunaan panduan oleh peserta didik menggunakan aplikasi LKPD Biologi m-Learning keterampilanketerampilan proses yang perlu dikembangkan oleh peserta didik diintergrasikan ke dalam setiap kegiatan yang harus dilakukan. Aplikasi LKPD yang dikembangkan menyediakan wadah berbentuk kegiatan pengamatan dan diskusi lalu peserta didik diminta untuk mengisinya dengan melakukan proses dalam rangka menemukan konsep yang hendak dikuasai pada materi ekosistem dan daur biogeokimia.

Tujuan dari pembelajaran sains adalah agar peserta didik mampu untuk menggunakan dan mengembangkan kompetensi keterampilan; dengan kata lain, mampu mendefinisikan dan menemukan permasalahan yang ada di sekitarnya, mengamati, menganalisis, menentukkan hipotesis, melakukan eksperimen, menarik kesimpulan, mengeneralisasi hasil yang diperoleh, dan mengaplikasikan informasi yang mereka miliki dengan keterampilan yang diperlukan (Aktamis \& Ergin, 2008, p.2). Fokus pada penilaian sains adalah peserta didik mampu mendemonstrasikan bahwa mereka mampu memahami dan menghargai ilmu pengetahuan yang mereka pelajari dan menerapkan pemahaman meraka di dalam kontes kehidupan sehari-hari (Chapietta \& Koballa, 2010, p.35). Sains sebagai proses merupakan serangkaian metode ilmiah untuk memecahkan persoalan. Biologi merupakan salah satu cabang sains yang melatih peserta didik dalam menemukan konsep kehidupan makhluk hidup melalui keterampilan proses sains. Pencapaian dan pengoptimalan dalam proses pembelajaran biologi melalui keterampilan proses sains didukung oleh potensi yang dimiliki peserta didik. Potensi peserta didik tersebut dapat ditingkatkan dan dikembangkan 
sesuai dengan tingkat perkembangan peserta didik.

Kompetensi keterampilan sains diperlukan untuk menggunakan informasi dan melakukan penelitian ilmiah guna memecahkan masalah-masalah yang dihadapi. Menurut Sheeba (2013, p.108), keterampilan penting diajarkan kepada peserta didik sejak sekolah dasar karena peserta didik lebih baik diajarkan "bagaimana mengetahui" dibandingkan "apa yang harus diketahui." Dalam Kurikulum 2013, peserta didik diisyaratkan untuk menguasai kompetensi secara keseluruhan, yang meliputi spiritual, pengetahuan, sosial, dan keterampilan sebagai suatu hasil penguasaan setelah melakukan proses pembelajaran. Dalam bidang IPA dikhususkan dengan penguasaan Keterampilan Proses Sains. Sehingga peserta didik memiliki pengalaman langsung dan dapat mengembangkan keterampilan yang harus dikuasai.

Rezba, Sparague, McDonnough, \& Matkins (2007, p.4) menyatakan "ways of thingking in science are called the process skill", yang berarti bagaimana cara dalam berpikir sains disebut sebagai keterampilan proses. Kegiatan sains melibatkan kemampuan berpikir seperti menduga (inferring), mengklasifikasi (classifying), berhipotesis (hypothesizing), dan melakukan percobaan (experimenting). Pengetahuan yang dihasilkan dari keterampilan tersebut, seharusnya mengembangkan nilai saintifik dan cara berpikir (habit on mind), dan konteks sosial menentukkan hakikat sains (nature of science). Namun kenyataannya, proses pembelajaran sains tidak selalu mencerminkan hakikat sains. Peserta didik seringkali merasa terbebani dengan pembelajaran singkat tentang fakta dan banyak istilah atau terminologi dengan mengorbankan kegiatan sains yang aktif. Beberapa penelitian yang mendukung gagasan bahwa peserta didik dapat belajar dengan baik apabila secara aktif berkegiatan secara fisik maupun mental, dengan aktivitas yang hand-on dan mind-on. Berdasarkan penelitian tersebut diperoleh kesepakatan diantara guru dan pembuat kebijakan bahwa "less is more", dimana fokus perhatian terbesar dengan sedikit konsep dan keterampilan yang lebih banyak akan jauh lebih bermanfaat bagi peserta didik daripada mencakup sejumlah besar konten sains yang bersifat abstrak. Aktivitas hands-on lebih mengarahkan ke proses pemahaman (mind-on), maksudnya adalah ketika guru lebih memfokuskan kepada bagaimana memberikan kesempatan peserta didik untuk menumbuhkembangkan kemampuan berpikir tentang apa yang mereka lakukan.

Dari penjabaran tersebut, dengan pemanfaatan aplikasi LKPD Biologi m-Learning berbasis Guided Discovery peserta didik dapat mengembangkan penguasaan kompetensi keterampilan yang harus dikuasai dan sekaligus meningkatkan pemahaman konsep pengetahuan yang dapat dilihat dari nilai hasil penguasaan kompetensi pengetahuan yang mereka peroleh. Handziko \& Suyanto, (2015, p.223), dalam penelitiannya tentang media pembelajaran ekosistem menyampaikan bahwa dari serangkaian analisis uji didapatkan kesimpulan empirik bahwa penggunaan media pembelajaran suksesi ekosistem Merapi pasca erupsi 2010 membawa perbedaan dan pengaruh yang signifikan pada penguasaan konsep suksesi dari peserta didik. Perbedaan dan pengaruh ini timbul karena media video dapat menampilkan proses pengamatan dan pengukuran ketika narator berinteraksi dengan objek. Saat narator berinteraksi dan melakukan pengamatan terhadap objek, itulah saat pengungkapan fakta di lapangan. Pengungkapan fakta ini penting untuk membangun konsep. Fakta yang didapat dari pengamatan dan pengukuran inilah yang kemudian dapat membangun sebuah konsep.

Hal ini juga sesuai dengan hasil penelitian yang dilakukan oleh Lati, Saksri, \& Vinich (2012, p. 4471-4472) bahwa pendekatan proses penemuan adalah salah satu pendekatan yang paling populer dalam kegiatan belajar sains karena dapat meningkatkan pemahaman konseptual serta keterampilan proses sains peserta didik. Yuliatun, Masykuri, \& Utami, (2017, p.4) menyatakan bahwa salah satu upaya untuk memperbaiki persoalan dalam pembelajaran adalah dengan menerapkan metode discovery learning pada pokok bahasan yang dirasa sulit dan perlu untuk ditingkatkan pemahaman serta penguasaannya. Penggunaan teknologi juga berperan penting dalam proses pembelajaran Mukti \& Nurcahyo (2017, p.12) "media pembelajaran biologi berbantuan komputer materi sistem pernapasan pada manusia hasil pengembangan layak digunakan untuk meningkatkan hasil belajar peserta didik."Pada penelitian ini, dengan pokok bahasan pada Ekosistem untuk kelas X semester genap, diperoleh hasil temuan bahwa aplikasi LKPD Biology m-Learning yang bernama "eco-Activity" berbasis Guided Discovery yang dikembangkan termasuk dalam kategori sangat baik sehingga layak untuk digunakan sebagai bahan ajar berdasarkan penilaian 
para ahli dan pendapat guru serta teman sejawat. Selain hal tersebut, penggunaan aplikasi LKPD Biology m-Learning "eco-Activity" oleh peserta didik secara efektif dapat meningkatkan penguasaan kompetensi dasar (pengetahuan dan keterampilan) yang harus dikuasai sesuai dengan Kurikulum 2013.

\section{SIMPULAN}

Penelitian desain dan pengembangan LKPD m-Learning berbasis Guided Discovery pada pokok bahasan Ekosistem dalam Kurikulum 2013 dilaksanakan dan dicapai sesuai dengan prosedur penelitian pengembangan Design and Development (D \& D R). Hasil pengujian dan penilaian oleh ahli, guru, teman sejawat, dan peserta didik diperoleh bahwa produk termasuk dalam kategori baik sehingga layak untuk digunakan dalam proses pembelajaran.

Pengujian dan penerapan aplikasi LKPD m-Learning berbasis Guided Discovery pada pokok bahasan Ekosistem efektif untuk meningkatkan hasil penguasaan kompetensi dasar (pengetahuan dan keterampilan) peserta didik, berdasarkan hasil uji Anacova dapat disimpulkan bahwa secara signifikan rata-rata nilai posttest penguasaan Kompetensi Dasar (KD) dalam Kurikulum 2013 peserta didik kelas eksperimen lebih tinggi dibandingkan kelas kontrol.

Rekomendasi untuk penelitian selanjutnya yakni Aplikasi LKPD m-Learning berbasis Guided Discovery pada pokok bahasan ekosistem yang dikembangkan diharapkan dapat diujikan lebih luas lagi di sekolah-sekolah, selain sekolah yang digunakan sebagai lokasi uji coba. Pengembangan m-Learning ini dapat diperluas dan dikembangkan oleh guru atau peneliti selanjutnya pada pokok bahasan yang lain maupun mata pelajaran lain.

\section{UCAPAN TERIMAKASIH}

Penulis menyampaikan rasa terima kasih kepada Prof. Dr. Djukri M.S. atas semua bimbingan dan kesempatannya kepada penulis selama masa penelitian.

\section{DAFTAR PUSTAKA}

Aktamis, H., \& Ergin, Ö. (2008). The effect of scientific process skills education on students' scientific creativity, science attitudes and academic achievements. Asia-Pacific Forum on Science Learning and Teaching, 9(1), pp. 1-21
Azwar, S. (2016). Tes prestasi: Fungsi dan pengembangan pengukuran prestasi belajar. Yogyakarta: Pustaka Pelajar.

Behera, S. K. (2015). Recent trend in ICT education. Solapur: Laxmi Book Publication.

Chiappetta, E. L., \& Koballa Jr, T. R. (2014). Science instruction in the middle and secondary schools. New York, NY.: Allyn \& Bacon.

DeRosa, D. A., \& Abruscato, J. A. (2014). Teaching children science: A discovery approach. Pearson Higher Ed.

Ellis, T. J., \& Levy, Y. (2010, June). A guide for novice researchers: Design and development research methods. In Proceedings of Informing Science \& IT Education Conference (InSITE) (pp. 107118). Retrieved from http://proceedings.informingscience.org/In SITE2010/InSITE10p107-118Ellis725.pdf

Hake, R. R. (1999). Analyzing change/gain scores. Retrieved from: http://www. physics.indiana.edu/ sdi/AnalyzingChang e-Gain.pdf.

Handziko, R. C., \& Suyanto, S. (2015). Pengembangan video pembelajaran suksesi ekosistem untuk meningkatkan motivasi belajar dan penguasaan konsep mahasiswa biologi. Jurnal Inovasi Pendidikan IPA, $1(2), \quad 212$. https://doi.org/10.21831/jipi.v1i2.7508

Karsli, F., \& Şahin, Ç. (2009). Developing worksheet based on science process skills: Factors affecting solubility. Asia-Pacific Forum on Science Learning and Teaching. 10 (15), 1-3. Retrieved from https://www.eduhk.hk/apfslt/download/v1 0_issue1_files/sahin.pdf

Lati, W., Supasorn, S., \& Promarak, V. (2012). Enhancement of learning achievement and integrated science process skills using science inquiry learning activities of chemical reaction rates. Procedia-Social and Behavioral Sciences, 46, 4471-4475.. Retrieved from http://www.sciencedirect.com/science/artic le/pii/S1877042812020150

Lee, A. T., Hairston, R. V., Thames, R., Lawrence, T., \& Herron, S. S. (2002). Using a computer simulation to teach science process skills to college biology and elementary majors. Bioscene, 28(4), 
35.

Retrieved

http://aquila.usm.edu/fac_pubs/14849

Moeed, A. (2015). Science investigation: Student views about learning, motivation and assessment. Springer.

Mukti, I., \& Nurcahyo, H. (2017). Pengembangan media pembelajaran biologi berbantuan komputer untuk meningkatkan hasil belajar peserta didik. Jurnal Inovasi Pendidikan IPA, 3(2), 137149.

doi:http://dx.doi.org/10.21831/jipi.v3i2.76 44

Oakes, J. M. (1997). Discovery through graphing. The Science Teacher, 64(1), 33.

Odum, E. P. (1998). Dasar-dasar Ekologi: Terjemahan dari Fundamentals of Ecology. Alih Bahasa Samingan, T. Edisi Ketiga. Universitas Gadjah Mada Press, Yogyakarta, 697.

Pachler, N., Bachmair, B., \& Cook, J. (2009). Mobile learning: structures, agency, practices. Springer Science \& Business Media.

Peraturan Menteri Pendidikan dan Kebudayaan Republik Indonesia Nomor 24 Tahun 2016 tentang Kompetensi Inti dan Kompetensi Dasar Pelajaran pada Kurikulum 2013 pada Pendidikan Dasar dan Menengah

Prayitno, B. A. (2011). Pengembangan perangkat pembelajaran IPA Biologi SMP berbasis inkuiri terbimbing dipadu kooperatif STAD serta pengaruhnya terhadap kemampuan berpikir tingkat tinggi, metakognisi, dan keterampilan proses sains pada siswa berkemampuan akademik atas dan bawah. Doctoral dissertation, Universitas Negeri Malang.

Rezba, R. J., Sparague, C., McDonnough, J. T., \& Matkins, J. J. (2007). Learning and assessing science process skills. Lowa: Kendall/ Hunt Publishing Company.

Richey, R. C., \& Klein, J. D. (2014). Design and development research: Methods, strategies, and issues. Routledge.

Sarrab, M., Elgamel, L., \& Aldabbas, H. (2012). Mobile learning (m-learning) and educational environments. International journal of distributed and parallel systems, $3(4), \quad 31 . \quad$ Retrieved from https://www.researchgate.net/publication/2 62488863_Mobile_Learning_M-

Learning_and_Educational_Environments

Shieh, C. J., \& Yu, L. (2016). A study on information technology integrated guided discovery instruction towards students' learning achievement and learning retention. EURASIA J. Math., Sci Tech. Ed. 12(4), 833-842. https://doi.org/10.12973/eurasia.2015.1554 a

Smaldino, S. E., Lowther, D. L., Russell, J. D., \& Mims, C. (2008). Instructional technology and media for learning. Boston: Allyn and Bacon.

Subali, B. (2016). Prinsip asesmen dan evaluasi pembelajaran. Yogyakarta: UNY Press

Sund, R. B., \& Carin, A. A. (1989). Teaching science through discovery. Columbus, Ohio: Charles Merril Publishing Company.

Susilana, R. \& Riyana, C. (2008). Media Pembelajaran. Bandung: Wacana Prima.

Yuliatun, L., Masykuri, M., \& Utami, B. (2017). Discovery learning with hierarchy concept to improve analysis ability and study achievement hydrolysis subject. Jurnal Inovasi Pendidikan IPA, 3(2), 172-179. doi:http://dx.doi.org/10.21831/jipi.v3i2.13 919 